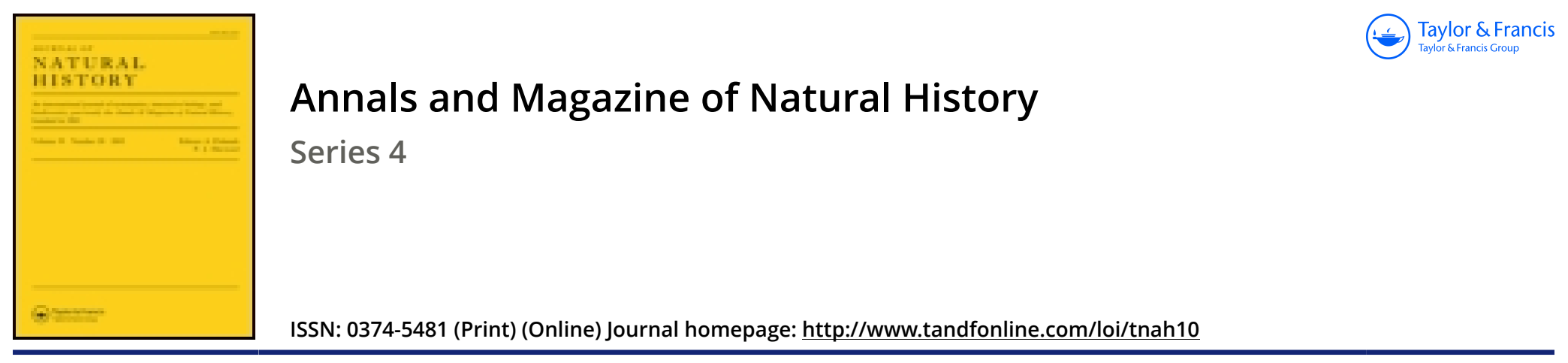

\title{
XLIV.-Description of a butterfly from Madagascar forming a new genus, from the collection of Henley Grose Smith and (by his benevolence) of W. C. Hewitson
}

\section{W.C. Hewitson F.L.S.}

To cite this article: W.C. Hewitson F.L.S. (1874) XLIV.-Description of a butterfly from Madagascar forming a new genus, from the collection of Henley Grose Smith and (by his benevolence) of W. C. Hewitson , Annals and Magazine of Natural History, 14:83, 359-360, DOI: $10.1080 / 00222937408680984$

To link to this article: http://dx.doi.org/10.1080/00222937408680984

\section{Published online: 13 Oct 2009.}

Submit your article to this journal ए

\section{Џll Article views: 3}


XLIV.-Description of a Butterfly from Madagascar forming a new Genus, from the Collection of Henley Grose Smith and (by his benevolence) of W. C. Hewitson. By W. C. Hewitson, F.L.S.

\section{Smerina, n. gen.}

Body of moderate size, half the length of the posterior wing. Anterior wing produced at the apex, slightly sinuated on the outer margin. Posterior wing produced at the anal angle.

Head large. Eyes hairy. Palpi large, spatulate, twice as long as the head, covered with hair, the last joint minute. Antennæ long, distinctly clubbed.

Anterior wing with the costal nervure half the length of the wing: subcostal with four branches-two before the end of the cell, two near together halfway between the end of the cell and the apex: the cell two fifths the length of the wing, closed in a regular curve; the first discocellular nervure minute, the second and third of equal length.

Posterior wing with the cell short, scarcely a third the length of the wing, closed obliquely.

Fore legs (male) of moderate length, the femur, tibia, and tarsus (which is covered with long hair) of equal length.

Four hind legs very long: the femur (which is covered with hair) and the tibia of equal length; the tarsus longer, covered beneath with spines.

\section{Smerina Vindonissa.}

Upperside. Female ferruginous. Anterior wing with two linear spots in the cell and one at the end of the cell, a large spot from the costal margin beyond its middle, the costal margin, the apex, and outer margin (where it is broad), and three spots near its inner border, all dark brown. Posterior wing crossed beyond the middle by a series of four or five black spots, and by two submarginal undulate bands of the same colour: the outer margin dark brown.

Underside pale brown. Both wings crossed from the costal margin of the anterior wing, beyond its middle, to the anal angle of the posterior wing by a common narrow dark-brown band, bordered outwardly with silver-lilac: both wings crossed beyond this by a series of brown spots and by two submarginal indistinct bands of the same colour. Anterior wing with two silver spots within the cell : a black line on each side of the discocellular nervures, and a band from the middle of the costal margin, which joins the central band ant encloses a pale glossy 
pink spot: three small apical spots and one near the anal angle silver. Posterior wing with a series of linear spots above the central band: irrorated with silver at the anal angle.

Male like the female, except that it is brick-red on the underside.

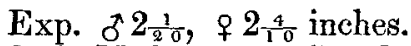

Hab. Madagascar (Crossley).

In colour and form this species resembles Atella Sinha, but without the tail.

XLV.-On a Collection of Hemiptera Heteroptera from Japan. Descriptions of various new Genera and Species. By JOHN SCOTT.

[Continued from p. 304.]

Family Urostylidæ.

Genus URostylis, Westwood.

Urostylis striicornis.

Testaceous or drab, black-punctured. Antenne yellow; first joint with a fuscous streak exteriorly; third entirely, and apical half of the fourth and fifth black. Membrane pale, with four dark fuscous streaks between the nerves, extending from the base to the apex.

Head testaceous or drab, unpunctured. Antennae yellow; first joint exteriorly with a fuscous streak, becoming paler towards the apex; third entirely, and apical half of the fourth and fifth black. Rostrum yellow; apex black.

Thorax.-Pronotum testaceous or drab, very sparingly clothed with fine, erect, pale hairs; lateral margins narrow, paler than the disk, the latter irregularly black-punctured. Scutellum irregularly black-punctured. Elytra testaceous or drab. Clavus with two rows of black punctures, viz. one along the scutellar margin, the other along the inner margin of the nerve; between the latter and the suture frequently three or four black punctures. Corium with a row of black punctures next the claval suture; disk irregularly blackpunctured, more sparingly than on the pronotum. Membrane pale; base between the second exterior and the inner nerve broadly fuscous, the four spaces between the third exterior and inner nerve fuscous. Sternum yellow or drab. Legs yellow or drab: tibiae, knees of all the pairs black.

$A b d o m e n$ entirely yellow or drab; last genital segment of 